\title{
Ambience and Customer Loyalty of the Sport-themed Restaurant
}

\author{
Jen-Son Cheng ${ }^{1}$, Hsin-Yu Shih ${ }^{2}$, Ming-Hsuan Wu ${ }^{2, *}$ \\ ${ }^{1}$ Department of Tourism, Leisure and Hospitality Management, National Chi Nan University, Taiwan \\ ${ }^{2}$ Department of International Business Studies, National Chi Nan University, Taiwan
}

Copyright $(2016$ by authors, all rights reserved. Authors agree that this article remains permanently open access under the terms of the Creative Commons Attribution License 4.0 International License

\begin{abstract}
Restaurant atmosphere can produce hedonic and practical shopping value and induce consumption loyalty. The aim of this study is to construct a consumer behavior model regarding the restaurant atmosphere, experiential value, restaurant image, and consumption loyalty by using a Sport-themed Restaurant. Regarding the materials and methods, the sample frame is a Sport-themed Restaurant in kaohsiung, Taiwan. Data were from employee convenience sampling with personal interview to collect data. The research targets obtain around 400 useful questionnaires. Regression analysis is to be used to test hypothesis. The results show that (1) Sport-themed restaurant atmosphere positively impacts experiential value, (2) experiential value positively impacts restaurant image, (3) restaurant image positively impacts consumption loyalty, and (4) restaurant atmosphere positively impacts consumption loyalty. The conclusion of this study includes that hypotheses 1, 2 and 3 are supported and this study also makes suggestion for the practitioners to plan and manage Sport-themed Restaurant in Taiwan.
\end{abstract}

Keywords Restaurant Atmosphere, Experiential Value, Restaurant Image, Consumption Loyalty

\section{Introduction}

There are a lot of studies regarding the effect of restaurant atmosphere on customers' buying behaviors. These studies suggest that customers' buying decision is affected not only by the quality of product or service itself, but also the environment where the transaction took place. Kolter [26] is amongst the first to propose that restaurant environment is sometime more important than the product itself in terms of persuade customers to purchase. Spence et al. [43] and Nistorescu \& Barbu [35] stated that the restaurant environment may include a lot of elements ranging from interior decoration to human components. These elements can generally be categorized into two aspects, namely internal and external.

Rook[36] and Saad \& Metawie [37] stated that the store is a place where merchandizes are sold to customers who might be purchasing based on an unplanned impulsive behavior. Creating a nice environment can help to prolong the time that customers linger in the store and increase the possibility of buying. Babin \& Darden, [2] and Muhammad, Musa \& Ali [34] suggested that store environment can enhance the hedonic and utilitarian values of the product, which is a strong incentive to encourage purchase decision. Lavidge \& Steiner [27] and Joshi \& Rahman [22] explained that this is due to a fact that customers' emotion is a major determinant in purchase behaviors. Sirgy, Grewal \& Mangleburg [41] and Hanzaee \& Javanbakht [19] asserted that creating a desirable shopping environment to induce positive emotion is than an important marketing strategy. Dabija \& Băbuț [10], Babin \& Darden, [2] and Sherman, et al. [40] confirmed that the impact of restaurant environment is not limited to increase purchase intention, but also extend to the improvement of satisfaction and loyalty.

\section{Materials and Methods}

\subsection{Literature Review}

Bitner [6] asserted that store environment is one of the key determinants in the success of business, especially in retail industry where environment is a key contributor for experiential value. Physical environment and the ambience is a vital part of a store's image(Sharma \& Stafford, [39]). A good restaurant environment created by the combination of lighting, music and color can help to stimulate customers' emotional responses, which helped to encourage impulsive buying. Utilitarian aspect of restaurant environment, on the other hand, can help the customers to form their cognitive appreciation, (Donovan, Rossiter, Marcoolyn, \& Nesdale, [13]), which helped to form rational buying decision.

According to past study (Engel, Blackwell, \& Kollart, [14]) at least $50 \%$ of supermarket customers made their decision 
impulsively. Welles (cited in: Madhavaram \& Laverie, [30]) found that 9 out of 10 shop browsers exhibit impulsive buying behavior. Ahtola[1] noted that approximately $50 \%$ of customers did not plan for their shopping activity, which leads to unplanned impulsive behavior. These studies agreed that the main reason that causes impulsive buying is restaurant environment. Restaurant environment can help to elevate cognitive perception of the value of a product or service. Restaurant environment can interact with customers to create an enjoyable circumstance and contribute to impulsive buying behavior (Madhavaram \& Laverie, [30]).

Sirgy et al. [41] proposed a model that helped to describe the interrelationships between restaurant environment, restaurant patron image, shoppers' self-concept, self-congruity, functional congruity, and retail patronage. The result indicates certain moderating and mediating effect between the constructs. Restaurant environment is able to produce a desirable situation that stimulates patronage. Furthermore, it has the ability to enhance the shopping experience and thereby improve customer loyalty (Babin \& Darden [2]; Sherman, et al. [40]). Donovan \& Rossiter's [12] study also indicated that customers will be willing to linger in the restaurant if the environment is appealing, which usually translate to impulsive purchase behavior. The literature indicates that restaurant environment is an important determinant in customers' purchase decision process, which contribute to the motivation of the study.

\subsection{Hypotheses Development}

The subject of the study is a Sport-themed Restaurant. As a recreational entertainment provider, it is expected that the environment of Sport-themed Restaurant possess high arousing properties (van Rompay, Tanja-Dijkstra, Verhoeven, \& van Es, [45]). The study, therefore, develops the following hypothesis based on literature review to farther the understanding between environment and behavior.

Restaurant environment can trigger emotional response of customers probably started from Kolter's [26] assertion. The literature of environment affecting buying behaviors later spread to internet shopping (Katerattanakul, [23]). The study indicates that environment, virtual or actual, can help to arouse positive emotional responses from the customers if properly designed. The reason can be summarized in two words "flow experience", which is used to describe a state where one fully immersed in what they do. People are more focused and can better enjoy themselves when they are fully immersed in what they are doing (Klasen, Weber, Kircher, Mathiak, \& Mathiak, [25]). It is evident from these studies that environment can help to enhance experience. Therefore, the study made hypothesis H1.

H1: Restaurant ambience is positive effect on experiential value of customers.

Past studies (Sénécal, Gharbi, \& Nantel, [38]) indicated that flow experience can help to enhance hedonic aspect of experiential value, but not utilitarian aspect of the experience. The assertion suggests the multi-facet nature of experiential value. Fakeye and Crompton [15] asserted that destination image is an integrated perception of a place that the experience of each time of visit is incorporated and used to modifie the perceived image. Past experience is a major contributor for an image of a place (Birgit, [5]), which contribute to the hypothesis $\mathrm{H} 2$.

$\mathrm{H} 2$ : Experiential value is positive effect on restaurant image.

Bigné [4] proposed that destination image can affect the behaviors of tourists. Destination image is an emotional connection between tourists and a place (Davidoff \& Davidoff, [11]), which gradually translate to place attachment (Lee, [28]). Restaurant images work in simpler way to create customer satisfaction and loyalty (Bloemer \& De Ruyter, [7]; van Riel, Semeijn, Ribbink, \& Bomert-Peters, [44]). Therefore, the study makes the following hypothesis.

H3: Restaurant image is positive effect on loyalty.

Sirgy, et al. [41] asserted that physical environment of shop can help to persuade customer to purchase. Physical environment can create a favorable condition that induce patronage and generate positive image. It has been suggested that environment not only induce buying, but might also help to build satisfaction and loyalty (Babin \& Darden [2]; Sherman, et al. [40]). Enjoyable shopping environment is known to introduce impulsive buying Mattila \& Wirtz [32]), especially amongst hedonic buyers (Babin \& Darden [2]). Hence the study hypothesizes as follow.

H4: Restaurant Ambience is positive effect on restaurant loyalty.

The study, therefore, proposes a model that helps to explain the interrelationships between restaurant ambience, experiential value, restaurant image, and restaurant loyalty. The model is presented in Figure 1.

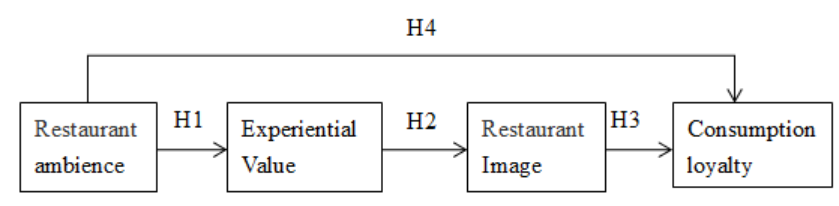

Figure 1. Research Framework

\subsection{Sampling Method}

The subject is a Sport-themed Restaurant in Kaohsiung city, Taiwan that prefers to remain anonymous. The survey is carried out during October to December, 2014. The clientele of the Sport-themed Restaurant were asked to complete the questionnaire, which is distributed with convenient sampling method.

The surveyors randomly approached individual customers at the sport-themed restaurant. The customer was first kindly asked whether he/she was above 18. The surveyors continued to distribute the survey if the customer responded yes. Otherwise, the surveyor thanked the customer and terminated the interview. It took averagely 15 min for a respondent to finish the survey. A total of 448 questionnaires were collected. After deleting 12 incomplete 
questionnaires, 436 valid responses remained for use in the study

\subsection{Questionnaire Design}

The questionnaire comprised of five parts including restaurant environment, experiential value, restaurant image, buying intention, and socio-demographic. The items of each dimensions are elicit from past studies. The restaurant environment part of the questions comprised 15 questions that can be allocated in three sub-categories namely social, ambience, and design (Baker, Parasuraman, Grewal, \& Voss, [3]). Experiential value aspect of questions are designed based on the work of Mathwick et al. [31], which further divided into four dimensions namely customer return on investment (ROI), aesthetics, playfulness, and service excellence. The restaurant image parts of the questions are designed based on past studies (Mitchell, [33]). The study incorporates and modifies past studies and proposes four sub-categories of restaurant image namely product, facility, service, and price images which consist of 12 questions. The loyalty comprises of four questions, which is based on works regarding customer loyalty (Hudson \& Gilbert, [20]). The above questions are in 5 point Likert scale where 1 denotes strongly disagree and 5 the opposite. The final part of the questionnaire is about respondents' socio-demographic information, such as age, gender, marital status, education level, occupation, and yearly salary.

\section{Results}

\subsection{Sample Characteristics}

The study collects a total of 436 responses where majority of them are male $(n=383,87.8 \%)$, which can be expected since the subject of the sport-themed restaurant. In terms of age groups, only 16 respondents below 21 years old, which is reasonable since young respondents may not be able to afford the service. There are 141 respondents $(32.3 \%)$ between 21 to 30 years old, 128 respondents $(29.4 \%)$ between 31 to 40 years old, 96 respondents $(22 \%)$ between 41 to 50 years old, and 55 respondents $(12.6 \%)$ are 51 years old or above. Most respondents possess university $(\mathrm{n}=147$, $33.7 \%$ ) level education, followed by high school equivalent education $(n=138,31.7 \%)$, and Technical college $(n=94$, $21.6 \%)$. Only very few respondents possess secondary school, primary school, or post-graduate degree. In terms of occupation, 139 respondents (31.9\%) are in service industry, 64 in business sector (14.7\%), 56 housekeepers (12.8\%), and 44 freelancers $(10.1 \%)$. There are very few respondents who are either retired, industrial worker, or farmers. The sport-themed Restaurant is a relative luxury commodity, which means only adult respondents with respectable income may afford the service. Indeed, there are 232 respondents
(53.2\%) spend more than NT\$1500 each time and 118 respondents $(27.1 \%)$ who spend more than NT\$1000. Reliability and Validity

The proposed model consists of four dimensions namely restaurant ambience, experiential value, restaurant image, and loyalty. The dimensions are subject to composite reliability (CR) test to ensure the internal consistency of the data and hence the reliability. The CR values for the dimensions are $0.931,0.854,0.916$, and 0.856 respectively. The values are above 0.7 , which is the suggested criterion for adequate reliability (Hair, Anderson, Tatham, \& Black, [17]). The study also calculates the average of variance extracted (AVE) for each dimension, which are 0.474, 0.593, 0.478, and 0.598 respectively. Researchers (Fornell \& Larcker, [16]) suggested that it is ideal to have AVE greater than 0.5 or at least 0.36 . Two of the dimensions are below the suggested level of 0.5 , but still acceptable. The indices suggest that the model possess adequate convergent validity. Therefore, the study can proceed with hypothesis testing.

\subsection{Hypothesis Testing}

The initial model fit indices are GFI $=0.844, \mathrm{CFI}=0.919$, and RMSEA $=0.058$. Hair et. al. [18] suggested that GFI should be higher than 0.9 or at least 0.8 , and RMSEA should be less than 0.05 or at least 0.08 . The GFI and RMSEA value of the model is not perfect in the original setting. Therefore, the study follows using MI as a guideline for modifying the model. AMOS provides modification index (MI) that served as an indicator for modifying the model to achieve better chi-square and consequently better model fit. Based on researchers' (Jöreskog, Sörbom, Du Toit, \& Du Toit, [21]) suggestion, item or dimension with MI greater than 3.84 should be removed or at least modified. However, since chi-square is very sensitive to large sample size, it has been suggested as a rule of thumb that only MI of greater than 20 should be treated as indication of misfit. The MI indicates that 10 pairs of error terms have MI higher than 20. These error terms are than linked with covariance path. The modification improve the indices to $\mathrm{GFI}=0.877$, CFI $=0.948$, and RMSEA $=0.047$. The RMSEA value effectively dropped below the suggested level of 0.05 . The other indices include $\mathrm{CMIN} / \mathrm{DF}=1.948$, which is suggested to be lower than 2 or higher than 5 by different authors (cited in: Loo \& Thorpe, [29]). The study, therefore, accept the modified model, which is presented in Figure 2.

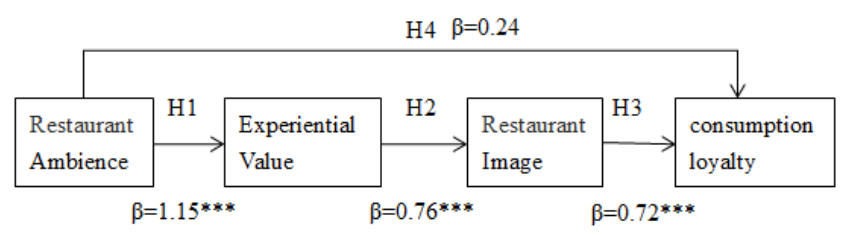

Figure 2. Hypothesis Testing 
Table 1. Regression Weights: (Group number 1 - Default model)

\begin{tabular}{|c|c|c|c|c|c|c|}
\hline & & & Estimate & S.E. & C.R. & P \\
\hline Experiential Value & $<---$ & Restaurant Ambience & 1.150 & .100 & 11.482 & $* * *$ \\
\hline Restaurant Image & $<---$ & Experiential Value & .766 & .064 & 12.045 & $* * *$ \\
\hline Restaurant Loyalty & $<---$ & Restaurant Image & .762 & .148 & 5.161 & $* * *$ \\
\hline Ambience & $<---$ & Restaurant Ambience & 1.000 & & & \\
\hline Design & $<---$ & Restaurant Ambience & 1.340 & .113 & 11.898 & $* * *$ \\
\hline Social & $<---$ & Restaurant Ambience & 1.203 & .111 & 10.883 & $* * *$ \\
\hline Product & $<---$ & Restaurant Image & 1.000 & & & \\
\hline Facility & $<---$ & Restaurant Image & 1.376 & .117 & 11.715 & $* * *$ \\
\hline Service & $<---$ & Restaurant Image & 1.010 & .089 & 11.348 & $* * *$ \\
\hline Price & $<---$ & Restaurant Image & 1.259 & .111 & 11.303 & $* * *$ \\
\hline Restaurant Loyalty & $<---$ & Restaurant Ambience & .244 & .139 & 1.750 & .080 \\
\hline
\end{tabular}

\section{Discussion}

The results in Table 1 are un-standardized regression weights of the proposed causal relations. The result shows that there are significant causal relationships between Restaurant Ambience and experiential value $(\beta=1.150$, $\mathrm{p}<0.001)$, experiential value and restaurant image $(\beta=0.766$, $\mathrm{p}<0.001$ ), and restaurant image and consumption loyalty $(\beta=0.762, p<0.001)$. These are indication that hypothesis $H 1$, $\mathrm{H} 2$, and $\mathrm{H} 3$ are supported. However, hypothesis H4 which postulates the causal relationship between Restaurant Ambience and consumption loyalty is not supported $(\beta=0.244, p=0.08)$.

There are also other interesting findings. First, facility dimension is the strongest contributor to restaurant image $(\beta=1.376, p<0.001)$, followed by price $(\beta=1.259, p<0.001)$. It is not surprising that customer has predisposition of wanting cheaper price. Therefore, it is understandable that reasonable price can help to build positive restaurant image. As for the importance of facility, it further strengthens the main theme of the study (i.e. the importance of physical environment). Furthermore, design dimension is a greatest contributor ( $\beta=1.34, p<0.001)$ followed by social dimension $(\beta=1.203$, $\mathrm{p}<0.001)$. The items in design dimension are referring to more tangible aspect of environment attribute which, such as architecture, restaurant layout, indoor decoration, and more. These elements cannot be easily changed, not without more investment anyway. Therefore, their ability to create a desirable restaurant environment is much more substantial. The ambience dimension referred to "soft" aspect of environmental attribute, such as music, lighting, aroma, and comfort. These elements, albeit important, can be changed quite easily.

The finding that H1 (Restaurant ambience is able to enhance experiential value of customers) is accepted is consistent with the following literature. This finding is supported by Katerattanakul [23] that declared that the environment affecting buying behaviors later spread to internet shopping. It is also consistent with the finding of Klasen, et al. [25] that people are more focused and can better enjoy themselves when they are fully immersed in what they are doing

The finding that $\mathrm{H} 2$ (Experiential value helped to form restaurant image) is accepted is consistent with the following literature. This finding is supported by Sénécal, et al. [38] who indicated that flow experience can help to enhance hedonic aspect of experiential value, but not utilitarian aspect of the experience. It is also consistent with the finding of Fakeye and Crompton [15] asserted that destination image is an integrated perception of a place that the experience of each time of visit is incorporated and used to modified the perceived image and Birgit [5] indicated that past experience is a major contributor for an image of a place.

The finding that H3 (Restaurant image contribute to restaurant Loyalty) is accepted is consistent with the following literature. This finding is supported by Bigné [4] proposed that destination image can affect the behaviors of tourists and van Riel, et al. [44] stated that restaurant image work in simpler way to create customer satisfaction and loyalty. It is also consistent with the finding of Davidoff \& Davidoff, [11] and Lee [28] stated that destination image is an emotional connection between tourists and a place, which gradually translate to place attachment.

The finding that H4 (Restaurant ambience contributes to Restaurant Loyalty) is not supported is different from the following literature. This could be something different from Sirgy, et al. [41] asserted that physical environment of shop can help to persuade customer to purchase. Therefore, more studies can be developed to explore the theories of Babin \& Darden [2] and Sherman, et al. [40] that environment not only can induce buying, but might also help to build satisfaction and loyalty and the assumptions of Mattila \& Wirtz [32] and Babin \& Darden [2] showed that enjoyable shopping environment is known to introduce impulsive buying, especially amongst hedonic buyers. 
Table 2. Summary of Hypothesis Testing

\begin{tabular}{|c|c|c|c|}
\hline Hypotheses & Content & Result & $\beta$ \\
\hline H1 & Restaurant Ambience $\rightarrow$ Experiential value & Supported & $1.15^{* * *}$ \\
\hline H2 & Experiential value $\rightarrow$ Restaurant image & Supported & $0.76^{* * *}$ \\
\hline H3 & Restaurant image $\rightarrow$ Restaurant Loyalty & Supported & $0.72^{* * *}$ \\
\hline H4 & Restaurant Ambience $\rightarrow$ Restaurant Loyalty & Not supported & 0.24 \\
\hline
\end{tabular}

\section{Conclusions}

\subsection{Conclusions}

Summary of the hypothesis testing is presented in Table 2 below. The result of hypothesis indicates that all the hypotheses are supported by the data, except H4. The interrelationship between the dimensions can thus be interpreted as follow. Restaurant ambience is an important component in generating positive experiential values that ultimately elevate customers' buying intention. However, restaurant ambience does not directly generate buying intention. The result of the study can also be explained by viewing and integrated result of numbers of past studies. Past studies has indicated that environment, physical (e.g. Countryman \& Jang, [9]) or virtual (e.g. Kim \& Fesenmaier, [24]), is effective in first impression formation. Furthermore, environment can enhance perceived quality of service and price acceptance (e.g. Baker, et al., [3]; Spangenberg, Crowley, \& Henderson, [42]). However, the result of this study indicates that environment can only impact customers' buying intention through arousing enjoyable experiential values and positive restaurant image. This finding is slightly similar to the result of online store study (e.g. Chang \& Chen, [8]). The result of such study suggests that online environment inspire trust and mitigate perceived risk, which is what eventually convince customers' patronage.

\subsection{Managerial Implication}

There are few managerial implications derived from the result of this study. First, the result of hypothesis testing indicates that restaurant ambience can only affect customers' buying intention indirectly. This suggests that when design restaurant ambience, practitioners cannot blindly invest on costly environment upgrades, but had to think about how environment evokes.

Second, the result indicates that "hard" aspect of restaurant attribute is a greater contributor for restaurant ambience than the "soft" aspect. Since "hard" aspect of restaurant attribute cannot be change without additional financial investment, it is important to design them carefully in the initial construction stage of the restaurant. The result also indicates that facility is the strongest contributor to restaurant image, which further strengthen the above point.

For restaurant management, study results indicate that restaurant Image has positive influence of consumption loyalty. Such a finding implies that restaurant should intensify of the product, facility, service, and price as a means of enhancing guest loyalty. For example, a sport-themed restaurant in fostering guest loyalty can consider targeting advanced product, facility, service, with the guests leading into loyalty.

\subsection{Recommendation for Future Studies}

As discussed previously, restaurant ambience cannot affect customers' buying intention directly. It is therefore important to understand what restaurant ambience can evoke. The study thus recommends future studies to include other dimensions, such as emotion in the study.

The result of the study also indicates that different aspects of restaurant ambience have different levels of contribution in the formation of restaurant ambience. It will be interesting to understand these elements further. Therefore, the study proposes that future study can try to understand the interrelationship between different aspects of restaurant ambience.

\section{REFERENCES}

[1] Ahtola, O. T. (1985). Hedonic and utilitarian aspects of consumer behavior: An attitudinal perspective. Advances in Consumer Research, 12(1), 7-10.

[2] Babin, B. J., \& Darden, W. R. (1995). Consumer self-regulation in a retail environment. Journal of Retailing, 71(1), 47-70.

[3] Baker, J., Parasuraman, A., Grewal, D., \& Voss, G. B. (2002). The influence of multiple store environment cues on perceived merchandise value and patronage intentions. The Journal of Marketing, 66(2), 120-141.

[4] Bigné, J. E., Sánchez, M. I., \& Sánchez, J. (2001). Tourism image, evaluation variables and after purchase behaviour: inter-relationship. Tourism Management, 22(6), 607-616.

[5] Birgit, L. (2001). Image segmentation: the case of a tourism destination. The Journal of Services Marketing, 15(1), 49.

[6] Bitner, M. J. (1995). Building service relationships: it's all about promises. Journal of the Academy of Marketing Science, 23(4), 246-251.

[7] Bloemer, J., \& De Ruyter, K. (1998). On the relationship between store image, store satisfaction and store loyalty. European Journal of Marketing, 32(5/6), 499-513.

[8] Chang, H. H., \& Chen, S. W. (2008). The impact of online store environment cues on purchase intention: Trust and 
perceived risk as a mediator. Online Information Review, $32(6), 818-841$.

[9] Countryman, C. C., \& Jang, S. (2006). The effects of atmospheric elements on customer impression: the case of hotel lobbies. International Journal of Contemporary Hospitality Management, 18(7), 534-545.

[10] Dabija, D. C., \& Băbuț, R. (2014). Enhancing Consumers' Satisfaction and Loyalty of Retailers in Romania through Store Ambiance and Communication. Procedia Economics and Finance, 15, 371-382.

[11] Davidoff, P. G., \& Davidoff, D. S. (1983). Sales and Marketing for Travel and Tourism Rapid City: National Publishers.

[12] Donovan, R. J., \& Rossiter, J. R. (1982). Store atmosphere: an environmental psychology approach. Journal of Retailing, $58(1), 34-57$.

[13] Donovan, R. J., Rossiter, J. R., Marcoolyn, G., \& Nesdale, A. (1994). Store atmosphere and purchasing behavior. Journal of Retailing, 70(3), 283-294.

[14] Engel, J. F., Blackwell, R., \& Kollart, D. T. (1978). Consumer Behavior. Hinsdale, IL: Dryden Press.

[15] Fakeye, P. C., \& Crompton, J. L. (1991). Image Differences between Prospective, First-Time, and Repeat Visitors to the Lower Rio Grande Valley Journal of Travel Research, 30(2), $10-16$.

[16] Fornell, C., \& Larcker, D. F. (1981). Evaluating structural equation models with unobservable variables and measurement error. Journal of Marketing Research, 39-50.

[17] Hair, J. F., Anderson, R. E., Tatham, R. L., \& Black, W. C. (1998). Multivariate analysis: Englewood: Prentice Hall International.

[18] Hair, J. F., William, C. B., Barry, J. B., \& Rolph, E. A. (2009). Multivariate Data Analysis (7 ed.). Upper Saddle River: Prentice Hall.

[19] Hanzaee, K. H., \& Javanbakht, A. (2013). The effects of shopping environment on consumption emotions, perceived values and behavioral intentions. Management Science Letters, 3(9): 2501-2512.

[20] Hudson, S., \& Gilbert, D. (2000). Tourism constraints: The neglected dimension in consumer behaviour research. Journal of Travel \& Tourism Marketing, 8(4), 69-78.

[21] Jöreskog, K. G., Sörbom, D., Du Toit, S., \& Du Toit, M. (2000). Lisrel 8: New Statistical Features. Lincolnwood, IL: Scientific Software International.

[22] Joshi, Y. \& Rahman, Z. (2015). Factors Affecting Green Purchase Behaviour and Future Research Directions. International Strategic Management Review, 3(1-2): 128-143.

[23] Katerattanakul, P. (2002). Framework of effective web site design for business-to-consumer Internet commerce. INFOR Journal, 40(1), 57-70.

[24] Kim, H., \& Fesenmaier, D. R. (2008). Persuasive design of destination web sites: An analysis of first impression. Journal of Travel Research, 47(1), 3-13.

[25] Klasen, M., Weber, R., Kircher, T. T. J., Mathiak, K. A., \&
Mathiak, K. (2012). Neural contributions to flow experience during video game playing. Social cognitive and affective neuroscience, 7(4), 485-495.

[26] Kolter, P. (1974). Atmospherics as a marketing tool. Journal of Retailing, 49(4), 48-64.

[27] Lavidge, R. J., \& Steiner, G. A. (2000). A model for predictive measurements of advertising effectiveness. Advertising \& Society Review, 1(1), 59-62.

[28] Lee, C. C. (2001). Predicting Tourist Attachment to Destinations. Annals of Tourism Research, 28(1), 229-232.

[29] Loo, R., \& Thorpe, K. (2000). Confirmatory factor analyses of the full and short versions of the Marlowe-Crowne Social Desirability Scale. The Journal of Social Psychology, 140(5), 628-635.

[30] Madhavaram, S. R., \& Laverie, D. A. (2004). Exploring impulse purchasing on the internet. Advances in Consumer Research, 31(1), 59-66.

[31] Mathwick, C., Malhotra, N., \& Rigdon, E. (2001). Experiential value: conceptualization, measurement and application in the catalog and Internet shopping environment. Journal of Retailing, 77(1), 39-56.

[32] Mattila, A. S., \& Wirtz, J. (2001). Congruency of scent and music as a driver of in-store evaluations and behavior. Journal of Retailing, 77(2), 273-289.

[33] Mitchell, V. W. (2001). Re-conceptualizing consumer store image processing using perceived risk. Journal of Business Research, 54(2), 167-172.

[34] Muhammad, N. S., Musa, R., \& Ali, N. S. (2014). Unleashing the Effect of Store Atmospherics on Hedonic Experience and Store Loyalty. Procedia - Social and Behavioral Sciences, 130, 469-478.

[35] Nistorescu, T., \& Barbu, C. M. (2008). Retail store design and environment as branding support in the services marketing. Management and Marketing Journal, 6(1), 11-17.

[36] Rook, D. W. (1987). The buying impulse. Journal of Consumer Research, 14, 189-199.

[37] Saad, M., \& Metawie, M. (2015). Store Environment, Personality Factors and Impulse Buying Behavior in Egypt: The Mediating Roles of Shop Enjoyment and Impulse Buying Tendencies. Journal of Business and Management Sciences, 3(2): 69-77.

[38] Sénécal, S., Gharbi, J., \& Nantel, J. (2002). The Influence of Flow on Hedonic and Utilitarian Shopping Values. Paper presented at the Advances in Consumer Research.

[39] Sharma, A., \& Stafford, T. F. (2000). The effect of retail atmospherics on customers' perceptions of salespeople and customer persuasion: An empirical investigation. Journal of Business Research, 49(2), 183-191.

[40] Sherman, P. W., Reeve, H. K., \& Pfennig, D. W. (1997). Recognition systems. In J. R. Krebs \& N. B. Davies (Eds.), Behavioural Ecology: An Evolutionary Approach (pp. 69-96). Oxford, United Kingdom: Blackwell Scientific Publications.

[41] Sirgy, M. J., Grewal, D., \& Mangleburg, T. (2000). Retail environment, self-congruity, and retail patronage: An 
integrative model and a research agenda. Journal of Business Research, 49(2), 127-138.

[42] Spangenberg, E. R., Crowley, A. E., \& Henderson, P. W. (1996). Improving the store environment: do olfactory cues affect evaluations and behaviors? The Journal of Marketing, $60(2), 67-80$.

[43] Spence, C., Puccinelli, N. M., Grewal, D., \& Roggeveen, A. L. (2014). Store Atmospherics: A Multisensory Perspective. Psychology \& Marketing, 31(7): 472-488.
[44] van Riel, A. C. R., Semeijn, J., Ribbink, D., \& Bomert-Peters, Y. (2012). Waiting for service at the checkout: negative emotional responses, store image and overall satisfaction. Journal of Service Management, 23(2), 144-169.

[45] van Rompay, T. J. L., Tanja-Dijkstra, K., Verhoeven, J. W. M., \& van Es, A. F. (2012). On store design and consumer motivation spatial control and arousal in the retail context. Environment and Behavior, 44(6), 800-820. 